\title{
'Apparent Protein' in Human Urine: some Surface Film Measurements
}

\author{
BY A. L. TÁRNOKY \\ Group Laboratory, Mile End Hospital, London, E. 1
}

(Received 9 August 1950)

The traces of protein-like substances present in normal urine are rarely detected by routine laboratory tests. Surface-tension methods, widely used in protein chemistry, are more sensitive. Such a method was first applied to the determination of urinary protein by Gunton \& Burton (1947), who added diluted urine to an aqueous buffer solution at pH 6.4 and measured the area of the surface film at 9 dynes/cm. using an indicator drop. They reviewed the literature and recorded $3.7 \mathrm{mg} . / 100 \mathrm{ml}$. as the mean protein content of normal urine. A study of urinary proteins in tuberculosis patients made it desirable to extend this work. The first departures from Gunton \& Burton's technique were made to fit the available apparatus, and further simplifications were introduced. This modification of the method is described. Since neither Gunton \& Burton's method nor the present procedure involves purifying or characterizing the urinary proteins, the term 'apparent protein' is used here to denote the resultant of all surface-active substances present in undialysed urine. Fluctuations in the 'apparent protein' content of consecutive urine specimens were also determined in some normal and tuberculosis cases. Only sufficient data were collected to define the usefulness of the method, but the results are of interest on their own merit and are presented here.

\section{EXPERIMENTAL}

Equipment. A rectangular trough, liquid surface $331 \times 182 \mathrm{~mm}$., and two rigid barriers were used. These were all made of Perspex and were coated with paraffin which was frequently renewed. The $\mathrm{pH} \mathrm{6.4} \mathrm{buffer} \mathrm{was} \mathrm{prepared} \mathrm{as}$ described by Gunton \& Burton (1947) and was preserved with $\mathrm{CHCl}_{3}$. Technical White Oil was used as an indicator. A sample of this, darkened by heating in air, was mixed with unheated White Oil until the mixture, tested under experimental conditions, gave a convenient reading with a specimen of normal urine. The same oil was used throughout the work. Its approximate surface tension, measured by the capillary rise method (Glasstone, 1946), was 19.5 dynes $/ \mathrm{cm}$.

Collection of urine. Full specimens, preserved with thymol, were collected from three patients under prolonged observation, and midstream specimens, preserved with $\mathrm{CHCl}_{3}$, from all others. These were centrifuged, tested for the presence of protein $(25 \%(w / v)$ salicylosulphonic acid), reducing substances (Benedict's solution) and bile salts (Hay's test) and, where necessary, made just acid with acetic acid. The surface tension of these specimens remained unchanged for $30 \mathrm{hr}$.
Procedure. Measurements were made in daylight, facing a north window. Urine was added dropwise at about 1 drop every 2 sec. to the surface between the two barriers 210 $220 \mathrm{~mm}$. apart, from a $1 \mathrm{ml}$. pipette delivering $0.985 \mathrm{ml}$., held at about $60^{\circ}$ to the horizontal. Indicator oil was added 14-16 sec., later, to give a surface $25-30 \mathrm{~mm}$. in diameter. During the next 4-6 sec. the surface area was reduced until the oil film was violet when observed at an angle of $45^{\circ}$. After a pause of 28-32 sec. the area was gradually (4-6 sec.) diminished until the oil film became a first-order sky-blue.

The distance between the inner edges of the barriers was read, by means of a transparent ruler, to the nearest mm. on both sides of the tray, and the average was noted ("tray reading'). All determinations were made in duplicate; the results usually agreed within $4 \mathrm{~mm}$. up to tray readings of $100 \mathrm{~mm}$. and within $8 \mathrm{~mm}$. at higher values. Where the tray reading exceeded $150 \mathrm{~mm}$. the urine was diluted with water and the measurement repeated. Tray readings were converted into 'apparent protein' values by reference to the standard protein curve (Fig. 1). Results were reported to the nearest $0.5 \mathrm{mg} . / 100 \mathrm{ml}$. urine.

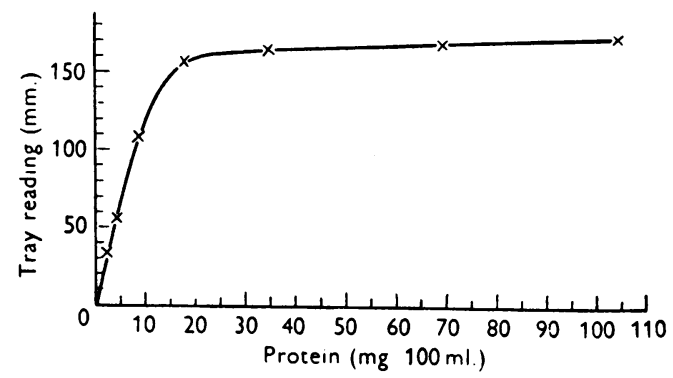

Fig. 1. Standard protein curve. Surface film measurements of diluted aqueous standard bovine albumin solutions.

Standard protein curve. A solution of bovine albumin in glass-distilled water was employed. It contained $1.49 \mathrm{~g}$. $\mathrm{N} / 100 \mathrm{ml}$. (Kjeldahl). Assuming the albumin to contain $15 \cdot 2 \%$ N (Putnam, Erickson, Volkin \& Neurath, 1943) this corresponds to $15.58 \mathrm{~g}$. albumin $/ 100 \mathrm{ml}$. solution. The carbohydrate content, determined by the method of Lustig \& Nassau (1941) against a standard glucose solution, was $0.24 \mathrm{~g} . / 100 \mathrm{~g}$. albumin. Surface-tension determinations were carried out on various aqueous dilutions of this solution. Tray readings (in $\mathrm{mm}$.) are plotted directly against albumin content (mg./100 ml. urine) in Fig. 1. All apparent protein values are thus expressed in terms of bovine albumin.

Observations relating to the method. The area of the indicator drop is not strictly controlled, and variations in its size affect the total measured area. This error is minimized by the relatively small area occupied by the oil drop which was $1-2 \%$ of the total expanded surface. Where the initial 
diameter of the drop diverged visibly from 25 to $30 \mathrm{~mm}$. the determination was repeated.

A time factor, due partly to the ageing of the protein film (Langmuir \& Waugh, 1940) and partly to the indicator oil, operates both in the expanded and the compressed state. The area at constant pressure decreases with time of standing, but the rate of decrease is slow if, as in the conditions described, reading is effected $50-60$ sec. after adding the urine. Longer standing is impracticable owing to the slow disintegration of the indicator oil.

Blank determinations with the apparatus and oil, omitting urine or adding $1 \mathrm{ml}$. water instead, gave tray readings of $5 \mathrm{~mm}$. or less. At these small areas there was usually some leakage across the barriers.

Gunton \& Burton (1947) found a second determination after precipitating the protein unnecessary for most purposes. They refer to Tsuchiya's reagent as satisfactory, but do not give details for its use. When used according to the ShevkyStafford method (Kolmer \& Boerner, 1945) this reagent interfered considerably with the surface tension of aqueous solutions and, owing to leakage due to ethanol, failed to give stable surface areas.

\section{RESULTS}

\section{'Apparent protein' content of random samples from healthy subjects and tuberculosis cases}

The normal group of forty-two cases consisted of healthy hospital staff, twenty-six male and sixteen female, between the ages of 18 and 60 years old. The thirty-eight tuberculosis cases (twenty-five male

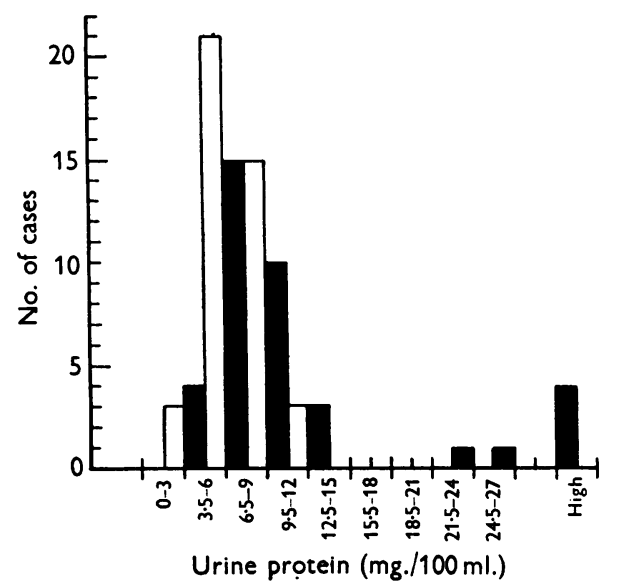

Fig. 2. Frequency distribution of apparent protein in random samples of urine from tuberculosis cases $(\square)$ and normal controls ( $\square$ ).

and thirteen female) were also between 18 and 60 years old. No attempt was made to control diets or the time of collection of the urine. Some of the tuberculosis group had a mild pyrexia; the qualitative Benedict test was positive in three cases and Hay's test in one case, while tests with $25 \%(w / v)$ salicylosulphonic acid showed traces of protein in seven cases.
The frequency distribution of all cases of both groups is shown in Fig. 2. Four patients had an apparent proteinuria of over $27 \mathrm{mg}$. $/ 100 \mathrm{ml}$. These are not included in the calculation below, since reference to the frequency distribution chart suggests that they form a group apart. The 'apparent protein' content of the normal group ranged from 1.5 to $11.5 \mathrm{mg} . / 100 \mathrm{ml}$., mean: $5.6 \mathrm{mg} . / 100 \mathrm{ml}$, S.D.: 2.03. The 'apparent protein' content in the tuberculosis group was upwards of $3.5 \mathrm{mg} . / 100 \mathrm{ml}$., mean of the $3.5-27 \mathrm{mg}$. group: $9.6 \mathrm{mg} . / 100 \mathrm{ml}$., S.D.: $4 \cdot 33$.

Gunton \& Burton (1947) record an average protein content of $3.7 \mathrm{mg} . / 100 \mathrm{ml}$. for normal urine. The corresponding value obtained by Wang \& Wu (1937) is $9 \mathrm{mg} . / 100 \mathrm{ml}$.

\section{Dilution curves}

The protein content of the urine from five patients with various diseases was determined by the use of $3 \%(w / v)$ salicylosulphonic acid and comparison with permanent standards (King \& Haslewood, 1936). The urines were diluted several times to give solutions of known protein contents, and surface tension curves were obtained (Fig. 3). The tray

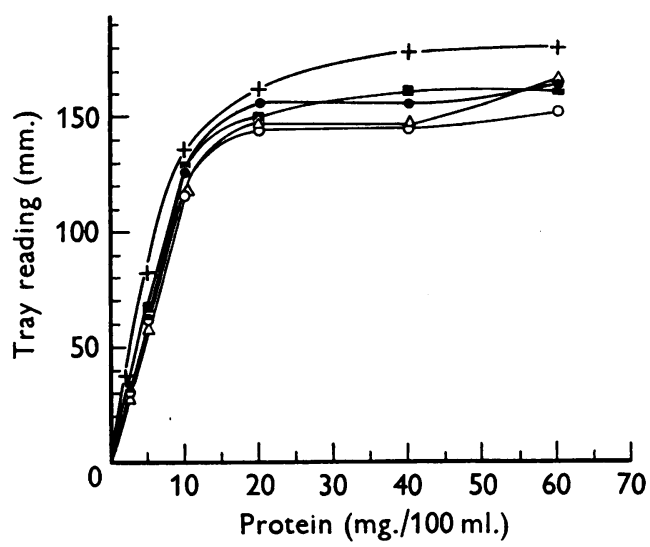

Fig. 3. Surface film measurements on human urine, using dilutions of known protein content. E. T. (pulmonary tuberculosis), $+-+;$ N. S. (diabetes mellitus, pulmonary tuberculosis and chronic pyelonephritis), O-O; F. W. (amyloidosis), - ; M. H. (diabetes mellitus and hypertensive heart failure), $\triangle-\triangle$; T. J. (coronary thrombosis), $\square-\square$.

readings of these dilutions as well as of the albumin standard solution were in an approximately linear proportion to the logarithm of the protein concentration up to about $20 \mathrm{mg}$./100 ml. (Fig. 4).

\section{'Apparent protein' excretion in individuals}

Since no data were available to show how the protein excretion of any individual varied throughout the day, it was not known whether a single pro- 
tein determination was in any way representative of any one case. The excretion of 'apparent protein' was therefore investigated in six cases, all males.

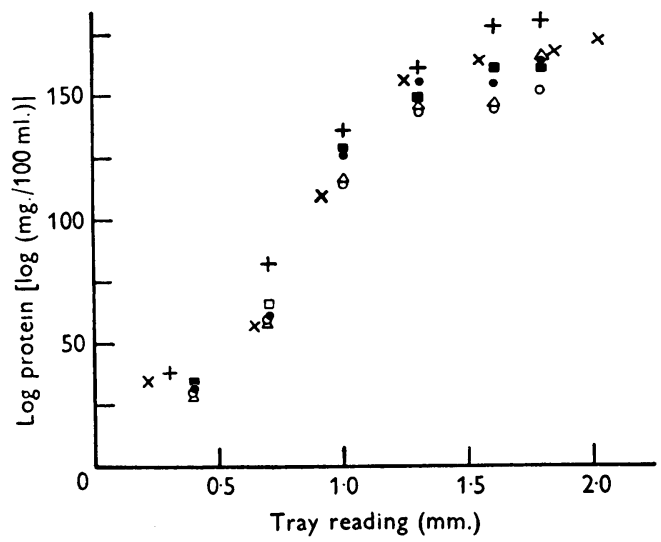

Fig. 4. Surface film measurements on standard protein solution and on human urine, using dilutions of known protein content. (Figs. 1 and 3 redrawn.) Standard bovine albumin solution, $x$; E.T., + ; N.S., O; F.W., O; M. H., $\triangle$; T. J., $\square$.

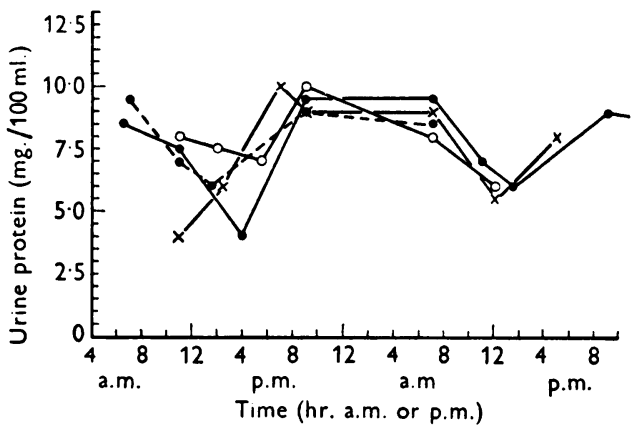

Fig. 5. 'Apparent protein' excretion in consecutive urine specimens. A. S. (pulmonary tuberculosis). Urine collection starting 15. iii. 50 (total excretion: $73 \mathrm{mg} . / 24 \mathrm{hr}$.) $\mathrm{O}-\mathrm{O}$; starting 22 . ii. 50 (61 mg./24 hr.) $\times-\times$.

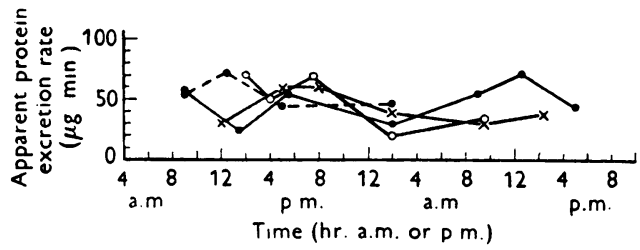

Fig. 6. A. S.: rate of excretion of 'apparent protein'. For notation see Fig. 5.

Three were healthy young adults and three patients with pulmonary tuberculosis, 30-40 years old, on bed rest but up in the afternoons. The diet was uncontrolled throughout. The normal cases collected midstream specimens of all urine passed over a period of $24 \mathrm{hr}$. or longer, and the fluctuation in 'apparent protein' content was noted. All urine from the patients was collected, and the volumes were recorded together with the "apparent protein" contents. This made it possible to calculate the 'apparent protein excretion rate', expressed in $\mu \mathrm{g}$. 'apparent protein' excreted per min., and referred to the time half-way between passing two successive specimens. The figures were calculated to the nearest $0.5 \mathrm{hr}$. Total daily excretions of 'apparent protein' were computed from the protein contents of complete specimens. The results of one case (A.S.) are shown in Figs. 5 and 6; all others are given in Table 1.

\section{DISCUSSION}

These determinations require accurate timing and a uniform technique. Once these have become a matter of routine, a large number of analyses can be made more simply than with Gunton \& Burton's (1947) equipment. A larger trough and an indicator oil of higher surface pressure enable most determina. tions to be carried out without diluting the urine. Measuring the distance between two movable barriers on both sides of the tray renders the usual barrier, rigidly fixed to a guide piece and scale, unnecessary; this simpler form of apparatus is easier to clean and to coat. Except at small surface areas, paraffin-coated surfaces are sufficiently hydrophobic, and no ferric stearate need be used.

The experimental error due to variations in the size of the indicator drop is minimized by the larger surface area of the protein film. A greater gain in accuracy is the high pressure of the indicator oil. Gunton \& Burton (1947) measure the area of protein layers at a surface pressure range where these are highly compressible (Adam, 1941). The present method lessens this source of error by using a range where the area of the protein film is relatively stable to minor changes in pressure. The general agreement between duplicate determinations indicates an overall accuracy no less than that recorded by Gunton \& Burton.

The nature of the protein film is not clear. It is of course not a pure protein, and the method of adding the urine makes it an inhomogeneous surface layer (Hughes \& Rideal, 1932). It is a solid film, as may be shown by sprinkling French chalk on the halfcompressed surface. The time effect may be due to the main film constituent or to non-protein impurities. Of these, bile salts suggest themselves as being both surface active and adsorbable on proteins; a negative Hay's test is no indication that small amounts are not present. Marfori (1941) found that the addition of sodium glycocholate to normal urine had an unexpectedly small effect on the surface tension, but this work would need extending before its conclusions could be applied here. The different physical 
Table 1. Diurnal variation in urinary 'apparent protein' excretion

(Dates refer to the collection of the first specimen in each series. Figures in brackets are 'apparent protein' excretions in $\mathrm{mg} . / 24 \mathrm{hr}$.)

Date

3. $x i .49$

28. xi. 49

2. xii. 49

18. xii. 49

8. i. 50

11. i. 50

27. ii. 50

8. iii. 50

Time of
collection $\begin{gathered}\text { Protein } \\ (\mathrm{mg} . / 100 \mathrm{ml} .)\end{gathered} \begin{gathered}\text { Excretion } \\ \text { rate } \\ (\mu \mathrm{g} . / \mathrm{min})\end{gathered}$

Subject, A.T., normal

11.30 a.m.
6.0 p.m.
6.0 p.m.
9.0 p.m.
7.30 a.m.
Noon

11.0 p.m.

8.0 a.m.

11.0 a.m.

4.30 p.m

7.0 p.m.

11.0 p.m.

8.0 a.m.

11.0 p.m.

8.30 a.m.

1.0 p.m.

6.0 p.m.

9.0 p.m.

9.0 a.m.

8.30 p.m.

10.30 p.m

8.30 a.m.

1.30 p.m.

5.0 p.m.

8.0 p.m.

Subject, J.W., normal

$\begin{array}{rlr}9.5 & - & 21 . \text { iii. } 50 \\ 11.5 & - & \\ 8.0 & - & \\ 7.5 & - & \\ 5.5 & - & 29 . \text { iii. } 50 \\ 9.0 & - & \end{array}$

11.30 p.m.

8.30 a.m.

11.0 a.m.

3.0 p.m.

7.0 p.m.

Midnight

8.0 a.m.

Midnight

8.0 a.m.

1.0 p.m.

6.0 p.m.

11.0 p.m.

8.0 a.m.

Midnight

8.30 a.m.

11.30 a.m.

5.0 p.m.

8.0 p.m.

Midnight

11.0 p.m.

8.0 a.m.

$11.30 \mathrm{a.m}$.

6.0 p.m.

11.0 p.m.

0.30 a.m.

8.0 a.m.

Subject, L.S., normal

$\begin{array}{cccc}10.30 \text { p.m. } & 6.0 & - & \\ 7.0 \text { a.m. } & 6.0 & - & \\ 11.30 \text { a.m. } & 7.0 & - & \text { 29. iii. } 50 \\ 2.30 \text { p.m. } & 7.0 & - & (51)\end{array}$

$$
5 \cdot 0
$$$$
10 \cdot 0
$$$$
6 \cdot 5
$$$$
\begin{array}{r}
5 \cdot 5 \\
6 \cdot 5
\end{array}
$$$$
7 \cdot 0
$$

6.5

10.5

$$
8 \cdot 5
$$$$
7 \cdot 0
$$$$
\begin{array}{r}
5 \cdot 5 \\
\mathbf{4} \cdot 5
\end{array}
$$$$
\mathbf{3} \cdot \mathbf{5}
$$$$
10 \cdot 0
$$$$
7 \cdot 0
$$$$
\text { 4.0 }
$$

mal 4.0

$11 \cdot 5$

$4 \cdot 0$

$4 \cdot 0$

$7 \cdot 0$

$5 \cdot 5$
$\mathbf{4} \cdot 5$

$\mathbf{3} \cdot \mathbf{0}$

$3 \cdot 0$
$2 \cdot 5$

4. 0

$2 \cdot 5$

$42 \cdot 0$

$2 \cdot 5$

8.5
3.5

$\mathbf{3} \cdot 5$
$8 \cdot 5$

$\mathbf{8} \cdot 5$
$5 \cdot 5$

$\mathbf{4 . 5}$

$7 \cdot 5$

$7 \cdot 5$

$2 \cdot 5$

$$
5 \cdot 5
$$

7.0 p.m.

10.30 p.m.

1.30 p.m.

7.30 p.m.

7.30 a.m.

11.0 a.m.

2.30 p.m.

6.30 p.m.
Date

$\begin{array}{ccc}\text { Time of } & \begin{array}{c}\text { Protein } \\ \text { collection }\end{array} & \begin{array}{c}\text { Excretion } \\ \text { rate }\end{array} \\ (\mathrm{mg} . / 100 \mathrm{ml} .) & (\mu \mathrm{min} .)\end{array}$ Subject, L.S., normal (cont.)

$\begin{array}{rr}\text { 1.30 p.m. } & 7 \cdot 0 \\ 7.30 \text { p.m. } & 7 \cdot 0 \\ 11.0 \text { p.m. } & 8 \cdot 5 \\ 8.0 \text { a.m. } & 8 \cdot 5 \\ 2.30 \text { p.m. } & 8 \cdot 0 \\ 12.30 \text { p.m. } & 7 \cdot 0 \\ 2.0 \text { p.m. } & 7 \cdot 0 \\ 5.30 \text { p.m. } & 6.5 \\ 7.30 \text { p.m. } & 8 \cdot 0 \\ 11.0 \text { p.m. } & 9.5 \\ 8.0 \text { a.m. } & 6.0 \\ 1.0 \text { p.m. } & 8.0\end{array}$

Subject, H.R., tuberculosis

6. xii. 49
(68)

9. xii. 49

(69)

12. xii. 49

(71)

15. xii. 49

(58)

22. iii. 50

(62)

\begin{tabular}{|c|c|c|}
\hline $\begin{array}{l}6.30 \text { a.m. } \\
9.30 \text { a.m. } \\
1.30 \text { p.m. } \\
7.0 \text { p.m. } \\
9.0 \text { p.m. } \\
6.30 \text { a.m. }\end{array}$ & $\begin{array}{l}2 \cdot 0 \\
8 \cdot 5 \\
6 \cdot 0 \\
8 \cdot 5 \\
8 \cdot 5 \\
5 \cdot 5\end{array}$ & $\begin{array}{r}80 \\
48 \\
50 \\
148 \\
18\end{array}$ \\
\hline $\begin{array}{l}2.0 \text { p.m. } \\
5.0 \text { p.m. } \\
9.0 \text { p.m. } \\
7.0 \text { a.m. } \\
10.30 \text { a.m. }\end{array}$ & $\begin{array}{l}6 \cdot 5 \\
5 \cdot 5 \\
8 \cdot 0 \\
6 \cdot 5 \\
6 \cdot 0\end{array}$ & $\begin{array}{l}59 \\
70 \\
23 \\
66\end{array}$ \\
\hline $\begin{array}{l}7.0 \text { a.m. } \\
0.0 \text { a.m. } \\
1.30 \text { p.m. } \\
5.0 \text { p.m. } \\
9.0 \text { p.m. } \\
6.30 \text { a.m. }\end{array}$ & $\begin{array}{r}6 \cdot 5 \\
6 \cdot 5 \\
5 \cdot 0 \\
4 \cdot 0 \\
12 \cdot 5 \\
6 \cdot 0\end{array}$ & $\begin{array}{r}76 \\
50 \\
44 \\
104 \\
25\end{array}$ \\
\hline $\begin{array}{l}0.0 \text { a.m. } \\
1.30 \text { p.m. } \\
5.0 \text { p.m. } \\
9.30 \text { p.m. } \\
7.0 \text { a.m. }\end{array}$ & $\begin{array}{l}\mathbf{5} \cdot 0 \\
\mathbf{8} \cdot 0 \\
\mathbf{3} \cdot 0 \\
\mathbf{3} \cdot 0 \\
\mathbf{9} \cdot 0\end{array}$ & $\begin{array}{l}78 \\
34 \\
23 \\
33\end{array}$ \\
\hline
\end{tabular}

25. iii. 50

(63)

Subject, F.B., tuberculosis

$$
11.30 \text { a.m. } \quad 11.5
$$

1.30 p.m.

4.0 p.m.

6.0 p.m.

7.30 p.m.

9.0 p.m.

6.0 a.m.

9.0 a.m.

11.0 a.m.

1.0 p.m.

5.30 p.m.

7.0 p.m.

9.0 p.m.

6.0 a.m.

10.0 a.m.

1.0 p.m.

2.0 p.m.

6.0 p.m.

6.30 p.m.

4.30 p.m.

7.0 p.m.

9.0 p.m.

6.30 a.m.

9.30 a.m.

11.0 a.m.

1.30 p.m.

4.0 p.m.

6.0 p.m.

6.30 p.m.

$7 \cdot 5 \quad 59$

$5.5 \quad 42$

$\begin{array}{ll}10 \cdot 0 & 83 \\ 10.5\end{array}$

$10.5 \quad 52$

$9.5 \quad 19$

$\begin{array}{ll}9 \cdot 5 & \mathbf{5 7}\end{array}$

$8.5 \quad 60$

$\begin{array}{ll}8.5 & 60\end{array}$

$7 \cdot 5 \quad 90$

$\begin{array}{rr}13.5 & 50 \\ 9 \cdot 0 & 56\end{array}$

$9 \cdot 0 \quad 16$

$12.5 \quad 42$

$\begin{array}{ll}10 \cdot 0 & 56\end{array}$

$\begin{array}{ll}4.5 & \mathbf{5 8}\end{array}$

$\begin{array}{rr}8 \cdot 0 & \mathbf{2 8 6}\end{array}$

6.0 54

$\begin{array}{rl}9 \cdot 0 & 64\end{array}$

$\begin{array}{rl}11.0 & 18\end{array}$

$\begin{array}{ll}7 \cdot 0 & \mathbf{3 2}\end{array}$

9.0 79

$9 \cdot 5$
$6 \cdot 5$

$5 \cdot 0 \quad 33$

6.0 50

$8.5 \quad 127$ 
nature of the films obtained by this technique and by Gunton \& Burton's method is shown well by the shape of the two standard protein curves.

The urinary proteins from cases with different diseases show no clear variation (Fig. 3), and all agree fairly closely with the standard protein curve. Most of the indicator oil films in this investigation were 'smooth circular' in the expanded state (Schaefer, 1938), but one tuberculosis urine gave a circular film surrounded by a halo-like zone, and one showed a 'star-like' expansion pattern. The standard protein solution and all urines used for the dilution curves of Fig. 3 gave 'star-like' oil drops at high protein concentrations, the points of the stars being toned down considerably below concentrations of $20 \mathrm{mg}$. $/ 100 \mathrm{ml}$. The shape of the oil film shows no qualitative difference in protein structure for the normal and tuberculous groups.

The study of the diurnal variation in the 'apparent protein' output of six cases allows one definite conclusion to be made: that while the collection of random samples can be a satisfactory way of comparing groups, no single specimen of urine is sufficiently representative of the average daily output of protein in the urine of any one person. Other observations are only of a tentative nature. Individual cases show some regularity both in the 'apparent protein' concentration of urine and its rate of excretion. Variations of the two quantities are related but not parallel, and their comparison in a greater number of cases may be of value in a study of postural proteinuria, of which these cases seem to show examples, and clinical conditions associated with low protein excretion. The day-to-day variation in $24 \mathrm{hr}$. protein excretion also seems more constant in any one person than has been reported by Wang \& $\mathrm{Wu}$ (1937).

\section{SUMMARY}

1. The surface-tension method of Gunton \& Burton (1947) has been simplified and modified for use with undiluted urine. Possible increases in the experimental error are offset by increased accuracy in the final step, where an indicator oil of a higher surface tension is used to measure the area at constant pressure of a solid surface film.

2. This method has been used to determine the 'apparent protein' content of urine from healthy and tuberculous subjects, the latter group giving higher values.

3. The fluctuation in the apparent proteinuria at various times of the day has been followed in six cases, and some regularity has been noted.

I should like to express my thanks to Dr E. Nassau (Pathologist, Harefield Hospital), at whose suggestion this work was carried out, for continuous help, discussions and suggestions; to Mr E. A. Evans (Chief Chemist, Research Department, C. C. Wakefield Ltd., Hayes) for a valuable discussion and a gift of the Technical White Oil used as indicator; and to many patients and members of the medical, laboratory and nursing staff of St Andrew's Hospital, London, E. 3, for organizing the collection of specimens, and their help throughout the investigation.

\section{REFERENCES}

Adam, N. K. (1941). The Physics and Chemistry of Surfaces, 3rd ed. Oxford: University Press.

Glasstone, S. (1946). The Elements of Physical Chemistry, New York: D. Van Nostrand.

Gunton, R. \& Burton, A. C. (1947). J. clin. Invest. 26, 892. Hughes, A. H. \& Rideal, E. K. (1932). Proc. roy. Soc. A, 137, 70.

King, E. J. \& Haslewood, G. A. D. (1936). Lancet, 2, 1153. Kolmer, J. A. \& Boerner, F. (1945). Approved Laboratory Technic, 4th ed. New York: D. Appleton-Century Co.
Langmuir, I. \& Waugh, D. F. (1940). J. Amer. chem. Soc. 62, 2771.

Lustig, B. \& Nassau, E. (1941). Amer. Rev. Tuberc. 43, 817.

Marfori, L. (1941). Policlinico, 48, 323. Taken from Chem. Abstr. 1947, 41, 4213g.

Putnam, F. W., Erickson, J. O., Volkin, E. \& Neurath, H. (1943). J. gen. Physiol. 26, 513.

Schaefer, V. J: (1938). J. phys. Chem. 42, 1089.

Wang, C.-F. \& Wu, H. (1937). Chin. J. Physiol. 12, 37. 